J. Swartz MD FRCPC, M. Cummings RN B SC, W. Pucci RT, D. Biehl MD FRCPC

\title{
The effects of general anaesthesia on the asphyxiated foetal lamb in utero
}

The effects of anaesthetic agents, per se, on the asphyxiated foetus are difficult to quantitate clinically. Anaesthesia is often necessary in foetal distress, however, to effect a rapid delivery. To investigate the effect of general anaesthetic agents commonly used for Caesarean section we administered these agents to 18 chronically prepared pregnant ewes with asphyxiated foetuses in utero. The foetuses were asphyxiated by partial occlusion of the umbilical cord until foetal arterial $\mathrm{pH}$ had decreased from 7.30 to a range of $7.08-7.13$. The animals were divided into three groups: Group A which received no anaesthesia and thus served as a control, Group $B$ which received thiopentone ( $3 \mathrm{mg} \cdot \mathrm{kg}^{-1}$ ) intravenously followed by 50 per cent nitrous oxide and 0.5 per cent halothane in oxygen for 15 minutes, and $G$ roup $C$ which received thiopentone ( $\left.3 \mathrm{mg} \cdot \mathrm{kg}^{-1}\right)$ followed by one per cent halothane in oxygen for 15 minutes. Foetal cerebral, myocardial, and renal blood flows were measured by injection of radioactive microspheres after production of asphyxia and after 5 and 15 minutes of anaesthesia.

General anaesthesia in both groups $B$ and $C$ abolished the hypertension and bradycardia produced by foetal asphyxia secondary to umbilical cord occlusion. There were no significant differences between Groups $B$ and $\mathrm{C}$ in foetal $\mathrm{pH}, \mathrm{PCO}_{2}$, or $\mathrm{PO}_{2}$. Two foetuses in the nitrous

\section{Key words}

COMPLICATIONS: asphyxia; ANAESTHETICS, GASES: nitrous oxide; ANAESTHETICS, VOLATILE: halothane; ANAESTHESIA: obstetric; PREGNANCY: umbilical cord occlusion.

From the Department of Anesthesia, University of Manitoba, Winnipeg, Manitoba.

Address correspondence to: Dr. D. Bichl, Department of Anesthesia, St. Boniface General Hospital, 409 Tache Avenue, Winnipeg, Manitoba, R2H 2 A6.

Supported by MRC Grant MA 6735 oxide group died after ten minutes of anaesthesia, but the aetiology of the sudden demise is unclear. We conclude that general anaesthesia abolishes the foetal response to umbilical cord occlusion and does not improve foetal oxygenation or acid-base status.

Intrapartum foetal distress occurs not uncommonly in the clinical situation, especially in the high-risk parturient. ${ }^{1,2}$ It is usually diagnosed from abnormal heart rate tracings, decreased foetal scalp pH, or the presence of meconium. ${ }^{3,4}$ Often, however, the degree of foetal asphyxia is difficult to quantitate. ${ }^{5}$ For this reason, the effects of anaesthetic agents on the stressed foetus is also difficult to assess clinically. Anaesthetic agents are often required to effect a rapid delivery - usually by Caesarean section if foetal asphyxia is strongly suspected; but the best combination of anaesthetic agents still remains to be determined.

In previous studies from our laboratory, we have used a model of foetal asphyxia involving partial occlusion of the umbilical cord to document the haemodynamics and acid-base changes that occur with time. ${ }^{6}$ In a previous experiment we subjected the asphyxiated foetus to anaesthesia with halothane. ${ }^{7}$ In this current study we have simulated the clinical situation of emergency Caesarean section by anaesthetizing pregnant ewes and asphyxiated foetuses with either thiopentone: $\mathrm{N}_{2} \mathrm{O}: \mathrm{O}_{2}$ and halothane or thiopentone: $\mathrm{O}_{2}$ : halothane to determine if either regimen adversely affects the asphyxiated foetal lamb.

\section{Methods}

Eighteen pregnant ewes of 125-135 days gestation (term 150 days) were surgically prepared as previously described, ${ }^{7}$ Briefly, under general anaesthesia polyvinyl catheters were placed in the maternal femoral artery and vein, the foetal femoral 
artery and vein, and the brachial artery. An inflatable occlusion loop was loosely secured around the umbilical cord. All animals were allowed to recover for $48-72$ hours following surgery. No animal was included in a study unless foetal arterial $\mathrm{PO}_{2}$ was greater than 15 torr and $\mathrm{pH}$ greater than 7.30. Prior to each study a maternal tracheostomy was performed under halothane in oxygen anaesthesia and the ewe allowed to recover for two hours.

During each study maternal and foetal mean arterial blood pressure and pulse rates were recorded continuously on a Hewlett-Packard multichannel recorder. Matemal blood gases and $\mathrm{pH}$ were measured at 15 -minute intervals. Foetal blood gases and $\mathrm{pH}$ were measured from the brachial artery at five-minute intervals or more frequently as required during asphyxia.

Each study began with a control period of 30 minutes to ensure stability of the preparation. The ewe breathed humidified oxygen at a flow of $15 \mathrm{~L} \cdot \mathrm{min}^{-1}$ via the tracheostomy. Then the umbilical cord occlusion loop was slowly inflated until foetal arterial $\mathrm{pH}$ was $7.08-7.13$. This usually required $60-90$ minutes.

When this $\mathrm{pH}$ range was obtained, the first microsphere injection was made. This technique had previously been described. ${ }^{7}$ Briefly, microspheres (diameter 10 micron, 3M Company, Minneapolis) labelled with either cerium, chromium, or strontium were injected into the foetal inferior vena cava while blood was withdrawn simultaneously from the femoral and brachial arteries at a rate of $3 \mathrm{ml} \cdot \mathrm{min}^{-1}$ from each artery for three minutes. These samples served as reference counts for blood flow above and below the ductus arteriosus.

Following the microsphere injection the animals were randomly placed into one of three groups. Group A, six control animals, received no anaesthesia but the ewes continued to breathe humidified oxygen for 15 minutes. The six ewes in Group B received thiopentone $\left(3 \mathrm{mg} \cdot \mathrm{kg}^{-1}\right)$ via the maternal femoral vein and were ventilated with 50 per cent nitrous oxide in oxygen with 0.5 per cent halothane. The six animals in Group $C$ received thiopentone ( $3 \mathrm{mg} \cdot \mathrm{kg}^{-1}$ ) intravenously followed by controlled ventilation with halothane, one per cent, in oxygen. In each group the occlusion loop was maintained inflated during the 15 minutes of anaesthesia. The second and third microsphere injections were made 5 and 15 minutes after induction of anaesthesia.

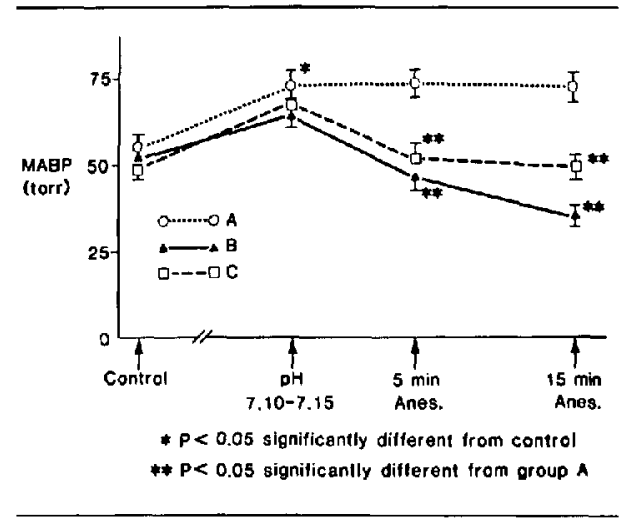

FIGURE 1 Foetal mean arterial blood pressure (MABP) Group A (control), Group B ( $\left.\mathrm{N}_{2} \mathrm{O}: \mathrm{O}_{2}\right)$ and Group $\mathrm{C}\left(\mathrm{O}_{2}\right.$-halothane) during severe asphyxia. $\mathrm{N}=6$. Mean $\pm \mathrm{SEM}$ during the three phases of the experiment.

Each ewe received normal saline intravenously at a rate of $150 \mathrm{ml} \cdot \mathrm{hr}^{-1}$ during the study.

After the third microsphere measurement all ewes and foetuses were killed with an injection of thiopentone, followed by $\mathrm{KCl}$. The foetuses were removed, weighed, and dissected. The foetal brain, heart, and kidneys were separately weighed, ground, and ashed. Microsphere counts were done on these samples and the counts were compared with the reference blood sample counts to calculate organ blood flow. ${ }^{8}$ Blood flow to the right and left kidney were calculated separately to serve as a marker for even distribution of microspheres to all organs. Discrepancy between right and left kidney flows suggests uneven mixing of the microspheres.

\section{Statistical analysis}

Maternal and foetal mean blood pressure (MABP), pulse rates, blood gases, $\mathrm{pH}$, and organ blood flows were subjected to analysis of variance to detect significant changes within groups. Inter-group comparsons were by unpaired " $\mathrm{t}$ " test for all data. $\mathrm{P}<0.05$ was considered significant.

\section{Results}

\section{Maternal changes}

There were no significant differences in pulse rate, $\mathrm{PCO}_{2}$, or B.E. in any group during the study. Mean arterial blood pressure (MABP) in Group $B$ $\left(\mathrm{N}_{2} \mathrm{O}: \mathrm{O}_{2}\right.$ :halothane) decreased with the onset of 


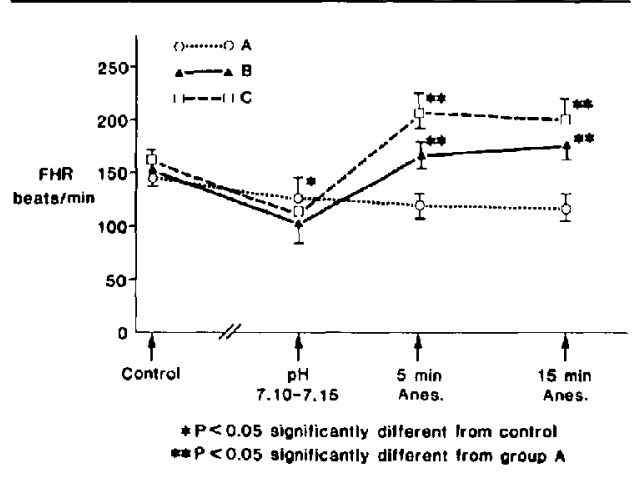

FIGURE 2 Foetal hear rate (FHR) Group A (control), Group $\mathrm{B}\left(\mathrm{N}_{2} \mathrm{O}: \mathrm{O}_{2}\right)$ and Group $\mathrm{C}\left(\mathrm{O}_{2}\right.$-halothane) during severe asphyxia. $\mathrm{N}=6$. Mean $\pm \mathrm{SEM}$ during the three phases of the experiment.

general anaesthesia and at 15 minutes had decreased from the control value of $86.0 \pm 4.1$ torr to $60.0 \pm$ 5.8 (mean \pm SEM). This was a significant change. There were no significant changes in MABP in Groups A or C. Maternal $\mathrm{PO}_{2}$ remained at control values in Groups $\mathrm{A}$ and $\mathrm{B}$ throughout the study, but rose significantly to Group $C$ following induction of anaesthesia and controlled ventilation with 99 per cent oxygen and one per cent halothane.

\section{Production of foetal asphyxia}

Inflation of the umbilical occlusion loop over a one to two hour period resulted in a statistically

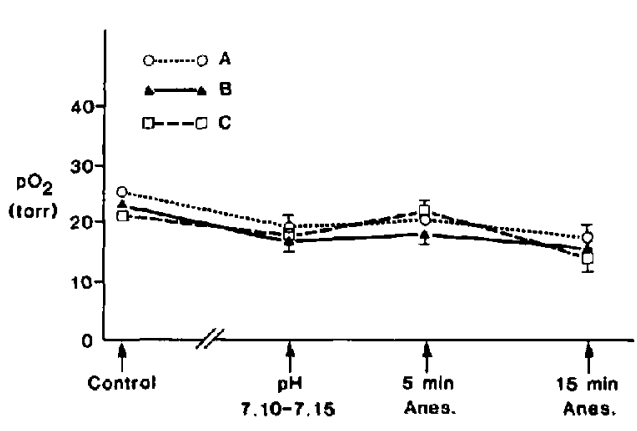

FIGURE 3 Foetal $\mathrm{PO}_{2}$ in Group A (control), Group B $\left(\mathrm{N}_{2} \mathrm{O}: \mathrm{O}_{2}\right.$ ) and Group $\mathrm{C}\left(\mathrm{O}_{2}\right.$-halothane) during severe asphyxia. $\mathrm{N}=6$. Mean \pm SEM measured from the brachial artery in each group during the three phases of the experiment.

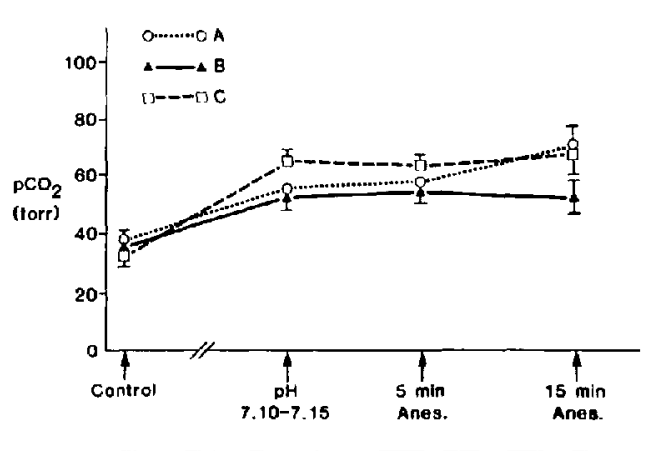

FIGURE 4 Foetal $\mathrm{PCO}_{2}$ in Group A (control), Group B $\left(\mathrm{N}_{2} \mathrm{O}: \mathrm{O}_{2}\right)$ and Group $\mathrm{C}\left(\mathrm{O}_{2}\right.$-halothane) during severe asphyxia $\mathrm{N}=6$. Mean \pm SEM measured from the brachial artery in each group during the three phases of the experiment.

significant decrease in foetal $\mathrm{pH}$ to a range of $7.08-7.13$ in each group. Foetal MABP increased from a range of $48-54$ torr in all groups to $68-72$ torr and heart rate decreased from a range of $150-155$ beats/min to $100-130$ after $60-90$ minutes These changes were significant (Figures 1, 2).

There were no significant changes in foetal $\mathrm{PO}_{2}$ measured from the brachial artery in any group during the production of foetal asphyxia (Figure 3 ). Foetal $\mathrm{PCO}_{2}$ rose significantly from $37-39$ torr to 53-65 tor after 90 minutes of cord occlusion (Figure 4). Foetal B.E. decreased from a range of -1 to 2 to -11 in all groups (Table I).

\section{Effects of general anaesthesia}

\section{Group A}

This group received no anaesthesia. There were no further significant changes in foetal heart rate, mean arterial blood pressure, blood gases, or $\mathrm{pH}$. All foetuses in this group survived the 15-minute study period.

\section{Group B}

$\left(\mathrm{O}_{2}: \mathrm{N}_{2} \mathrm{O}\right.$ :halothane $)$. Induction of general anaesthesia produced an increase in foetal heart rate from $100 \pm 9.3$ to $167 \pm 21.4$ within five minutes. The foetal tachycardia, significantly greater than control values, persisted for the duration of the study (Figure 2). Foetal hypertension was abolished, with a fall in MABP from $64.7 \pm 2.6$ to $36.4 \pm 2.2$ torr (Figure 1). This was significantly below initial 
TABLE I Foetal pH and B.E. during control, production of foetal asphyxia, and with general anaesthesia (Mean \pm SEM)

\begin{tabular}{|c|c|c|c|c|c|}
\hline & \multicolumn{2}{|l|}{ Conerol } & \multirow{2}{*}{$\frac{\text { Asphyxia }}{(\text { Foeral pH 7.08-7.13) }}$} & \multicolumn{2}{|c|}{$\begin{array}{l}\text { Asphyxia plus anaesthesia } \\
\text { (Group B,C) }\end{array}$} \\
\hline & $15 \mathrm{~min}$ & $30 \mathrm{~min}$ & & $5 \min$ & $15 \mathrm{~min}$ \\
\hline \multicolumn{6}{|l|}{$B . E}$. \\
\hline Group A & $\begin{array}{l}-2.9 \\
\pm 0.8\end{array}$ & $\begin{array}{l}-1.8 \\
\pm 1.4\end{array}$ & $\begin{array}{l}-10.1 * \\
\pm 0.9\end{array}$ & $\begin{array}{l}-12.6^{*} \\
\pm 0.9\end{array}$ & $\begin{array}{c}-14.6^{*} \\
\pm 0.7\end{array}$ \\
\hline Group B & $\begin{array}{l}-0.6 \\
\pm 1.6\end{array}$ & $\begin{array}{l}-0.3 \\
\pm 1.5\end{array}$ & $\begin{array}{r}-11.9^{*} \\
\pm 0.91\end{array}$ & $\begin{array}{c}-16.9^{*} \\
\pm 1.4\end{array}$ & $\begin{array}{l}-19.1^{*} \\
\pm 2.3\end{array}$ \\
\hline Group C & $\begin{aligned} & 2.4 \\
\pm & 1.39\end{aligned}$ & $\begin{array}{l}-2.94 \\
\pm 1.39\end{array}$ & $\begin{array}{r}-11.19 \\
\pm 0.74\end{array}$ & $\begin{array}{l}-13.24^{*} \\
\pm 1.07\end{array}$ & $\begin{array}{c}-15.36^{*} \\
\pm 2.37\end{array}$ \\
\hline$p H$ & & & & & \\
\hline Group A & $\begin{array}{r}7.34 \\
\pm 0.02\end{array}$ & $\begin{array}{r}7.36 \\
\pm 0.03\end{array}$ & $\begin{aligned} & 7.12^{*} \\
\pm & 0.01\end{aligned}$ & $\begin{aligned} & 7.09^{*} \\
\pm & 0.02\end{aligned}$ & $\begin{aligned} & 7.01^{*} \\
\pm & 0.02\end{aligned}$ \\
\hline Group B & $\begin{array}{r}7.39 \\
\pm 0.02\end{array}$ & $\begin{array}{r}7.39 \\
\pm 0.02\end{array}$ & $\begin{aligned} & 7.13^{*} \\
\pm & 0.01\end{aligned}$ & $\begin{array}{r}7.04 \\
\pm 0.03\end{array}$ & $\begin{aligned} & 7.00^{*} \\
\pm & 0.04\end{aligned}$ \\
\hline Group C & $\begin{array}{r}7.43 \\
\pm 0.16\end{array}$ & $\begin{array}{r}7.45 \\
\pm 0.21\end{array}$ & $\begin{aligned} & 7.08^{*} \\
\pm & 0.18\end{aligned}$ & $\begin{aligned} & 7.05^{*} \\
\pm & 0.25\end{aligned}$ & $\begin{aligned} & 6.99 * \\
\pm & 0.07\end{aligned}$ \\
\hline
\end{tabular}

* Significant changes from control values in each group ( $p<0.05$ ).

Group $A=$ no anaesthesia.

Group $\mathrm{B}=\mathrm{N}_{2} \mathrm{O}: \mathrm{O}_{2}$; halothane anaesthesia following establishment of asphyxia.

Group $\mathrm{C}=\mathrm{O}_{2}$; halothane anaesthesia following establishment of asphyxia.

control values. Foetal $\mathrm{PO}_{2}$ and $\mathrm{PCO}_{2}$ remained stable (Figures 3, 4). Foetal pH declined from 7.13 \pm .01 to $7.00 \pm .04$ (Table I). Two foetuses in this group did not survive the study. Both succumbed after ten minutes of general anaesthesia.

\section{Group C}

$\left(\mathrm{O}_{2}\right.$ :halothane). In this group general anaesthesia also abolished the bradycardia and hypertension of cord occlusion. Foetal heart rate rose from $131 \pm$ 2.2 to $198 \pm 17.4$. This increase was significantly higher than control values (Figure 4 ). With the onset of general anaesthesia, foetal MABP declined from $68.9 \pm 3.6$ torr to $52.3 \pm 4.6$ torr which was similar to the pre-asphyxia values (Figure 1). As in Group $\mathrm{B}$, foetal $\mathrm{PCO}_{2}$ and $\mathrm{PO}_{2}$ remained unchanged. In Group $\mathrm{C}$, there was no further significant fall in foetal $\mathrm{pH}$ and B.E. No foetus in Group $\mathrm{C}$ died during the study period.

\section{Foetal cerebral blood flow}

In each group total cerebral blood flow was in the range of $3.9-4.5 \mathrm{ml} \cdot \mathrm{g}^{-1} \cdot \mathrm{min}^{-1}$ after production of foetal asphyxia (Table II). There were no significant differences between groups. After 15 minutes of anaesthesia, mean cerebral blood flow in Group B had increased from $3.69 \pm .22 \mathrm{ml} \cdot \mathrm{g}^{-1} \cdot \mathrm{min}^{-1}$ to $4.86 \pm .55 \mathrm{ml} \cdot \mathrm{g}^{-1} \cdot \mathrm{min}^{-1}$, but this change was not significantly different. Cerebral blood flow in Groups $A$ and $C$ fell slightly after 15 minutes of anaesthesia but not significantly. There were no significant differences between groups in myocardial blood flow. There were no significant differences between flows to the left and right kidney.

\section{Discussion}

Umbilical cord compression precipitates both respiratory and metabolic acidosis. The metabolic component occurs due to decreased venous return with resultant hypovolemia and decreased cardiac output. The respiratory acidosis occurs because of impaired foetal umbilical blood flow to the placenta so that adequate gas exchange cannot occur. After a $\mathrm{pH}$ fall from 7.30 to 7.08 , the foetal lamb is still able to survive, however, for at least a further 15 minutes as seen in our present study, and longer, as documented in other work. ${ }^{9}$ With the stress of cord occlusion foetal blood pressure increases to maintain blood flow to vital structures. This increased MABP is likely due to peripheral vasocontriction 
TABLE II Organ blood flows $\left(\mathrm{ml} \cdot \mathrm{g}^{-1} \cdot \mathrm{min}^{-1}\right)$ just prior to, and after, 5 and 15 minutes of anaesthesia* (Mean \pm SEM)

\begin{tabular}{lrrr}
\hline & Control & 5 minutes & 15 minutes \\
\hline Brain & & & \\
Group A & 3.87 & 3.69 & 3.12 \\
& \pm 0.36 & \pm 0.45 & \pm 0.75 \\
Group B & 3.69 & 3.63 & 4.86 \\
& \pm 0.22 & \pm 0.47 & \pm 0.55 \\
Group C & 4.48 & 4.13 & 2.92 \\
& \pm 0.61 & \pm 0.60 & \pm 0.68 \\
& & & \\
Heart & & & \\
Group A & 2.46 & 1.70 & 2.34 \\
& \pm 0.61 & \pm 0.31 & \pm 0.40 \\
Group B & 2.17 & 1.99 & 2.94 \\
& \pm 0.62 & \pm 0.49 & \pm 0.24 \\
Group C & 2.48 & 2.80 & 2.13 \\
& \pm 0.39 & \pm 0.77 & \pm 0.58 \\
\hline
\end{tabular}

Renal blood flow

\begin{tabular}{lrrrrrr}
\hline & Right & Left & Right & Left & Right & \multicolumn{1}{c}{ Left } \\
\hline Group A & 0.67 & 0.67 & 0.59 & 0.61 & 0.51 & 0.56 \\
& \pm 0.10 & \pm 0.09 & \pm 0.08 & \pm 0.09 & \pm 0.13 & \pm 0.15 \\
Group B & 0.85 & 0.85 & 0.80 & 1.05 & 0.40 & 0.42 \\
& \pm 0.16 & \pm 0.15 & \pm 0.28 & \pm 0.07 & \pm 0.51 & \pm 0.57 \\
Group C & 0.44 & 0.42 & 0.57 & 0.55 & 0.61 & 0.46 \\
& \pm 0.10 & \pm 0.10 & \pm 0.08 & \pm 0.07 & \pm 0.08 & \pm 0.11 \\
\hline
\end{tabular}

*No significant changes within or between groups.

Group $A=$ no anaesthesia.

Group $\mathrm{B}=\mathrm{N}_{2} \mathrm{O}: \mathrm{O}_{2}$ :halothane anaesthesia following establishment of asphyxia.

Group $\mathrm{C}=\mathrm{O}_{2}$ :halothane anaesthesia following establishment of asphyxia.

mediated through the sympathetic nervous system. ${ }^{10}$ This mechanism offsets the drop in cardiac output due to the decreased venous return produced by partial cord occlusion. The decrease in heart rate indicates an intact baroreceptor response to hypertension. The consistent increased cerebral blood flow seen in this acidotic sheep model ${ }^{9}$ likely represents the foetal attempt to maintain oxygen supply to the brain in the face of acidosis and decreased oxygen content.

In our three groups of asphyxiated foetuses, there was no significant change in foetal arterial $\mathrm{PO}_{2}$ either with cord occlusion or anaesthesia. The decrease in $\mathrm{pH}$ and increase in $\mathrm{PCO}_{2}$ likely produces a shift in the oxy-haemoglobin dissociation curve, however, and should decrease oxygen content. This has been previously demonstrated by Johnson et al. ${ }^{9}$ Oxygen content was not measured in our study.

The induction of anaesthesia in Groups B and C abolished the hypertension and bradycardia produced by cord occlusion. In both groups the increase in heart rate did not maintain the foetal MABP at the pre-anaesthesia values. This may have some clinical relevance where reversal of a foetal bradycardia, often regarded as desirable, may not actually improve perfusion if cord occlusion is the instigating factor.

In Group B, the only group to receive nitrous oxide, two of six foetuses succumbed after ten minutes of anaesthesia. The explanation for this is not known. The factors which may explain this finding are: (1) the significant decrease in maternal arterial pressure which occurred in this group but not in Group $C$. This may have decreased placental blood flow. (2) The depth of anaesthesia may have been greater in these foetuses, or the use of nitrous oxide and halothane ${ }^{11,13}$ may have decreased myocardial contractility and reduced cardiac output. The interval between the death of these two foetuses and the termination of the experiment in the other animals may have been too short for changes in acid-base to become significant in the other foetuses in Group B. (3) Complete cessation of umbilical blood flow may have occurred because of the occlusion loop, which we were not able to detect.

General anaesthesia abolishes the hypertension and bradycardia seen with partial cord occlusion in the foetal lamb. When asphyxia is severe, $(\mathrm{pH}<$ 7.10) general anaesthesia does not improve foetal acid-base status but over a 10-15 minute period does not produce a significant fall in cerebral or myocardial blood flow. Time is an important factor here. At some point foetal reserve will be completely lost and foetal death will occur. All the factors which play a role in decreasing foetal reserve still remain to be determined.

The clinical situation of severe foetal distress may necessitate a general anaesthetic because there is insufficient time for a regional technique. While it is difficult to extrapolate from animal studies, our current findings from anaesthetizing severely asphyxiated foetal lambs would suggest that general anaesthesia will not improve the foetal condition and rapid delivery is essential. 


\section{References}

1 Manning FA, Morrison I, Lange IR, Harman C. Antepartum determination of fetal health: composite biophysical profile scoring. Clin Perinatol, 1982, 9: 285-96.

2 Cohen H. Fetal distress. Chapter 2 in Obstetric Anesthesia: The Complicated Patient. James FM, Wheeler AS, editors, F.A. Davis Co., Philadelphia, 1982.

3 Gimovsky $M L$, Carites $S N$. Diagnosis of management of hypoxic fetal heart rate patterns. Clin Perinatol 1982, 9: 297-312.

4 Fishburne JI. Fetal monitoring in high-risk pregnancy. Chapter 1 in Obstetric Anesthesia: The Complicated Patient. James FM, Wheeler AS, editors, F.A. Davis Co., Philadelphia, 1982.

5 Miller FC. Prediction of acid-base values from intrapartum fetal heart rate data and their correlation with scalp and funic values. Clin Perinatol, 1982, 9: 352-62.

6 Yarnell R, Biehl DR, Pucci W. Redistribution of cardiac output in foetal sheep in response to umbilical cord compression. SOAP Abstract, Vancouver, B.C. May, 1983.

7 Yarnell R. Biehl DR, Tweed WA et al. The effect of halothane anaesthesia on the asphyxiated foetal lamb in utero. Can Anaesth Soc J, 1983, 30: 474-9.

8 Rudolph AM, Heymann MA. The circulation of the fetus in utero: methods for studying distribution of blood flow, cardiac output, and organ blood flow. Cir Res, 1967, 21: 163-71.

9 Johnson GN, Palahniuk RJ, Tweed WA et al. Regional cerebral blood flow changes during severe asphyxia produced by slow partial umbilical cord compression. Am J Obstet Gynecol, 1979, 135: 148-52.

10 Hutson MJ, Mueller-Heubach E. Diagnosis and management of intrapartum reflex fetal heart rate changes. Clin Perinatol, 1982, 9: 325-38.

11 Goldberg AH, Sohn YZ, Phear WP. Direct myacardial effects of nitrous oxide. Anesthesiology, 1972, 37: 373-9.

12 Stoelting $R K$, Gibbs $P S$. Hemodynamics effects of morphinc and morphine-nitrous oxide in valvular heart disease and coronary artery disease. Anesthesiology, 1973, 38: 45-54.

13 Palahniuk RJ, Cumming $M$. Foetal deterioration following thopentone nitrous oxide anaesthesia in the pregnant ewe. Can Anaesth Soc J, 1977, 24 : $361-70$.
Résumé

Les effets des agents anesthésiques comme tels sur le fortus asphyxié sont difficiles à quantifier cliniquement. L'anesthésie est souvent nécessaire lors de la détresse fatale afin de procéder à un accouchement rapide. Afin d'investiguer les effets des agents anesthésiques utilisés fréquemment lors des césariennes, on a administré ces agents à 18 brebis gravides. Les fotus de ces brebis ont été préparés chroniquement de façon à les asphyxier in utero. Ces foetus ont été asphyxiés par une occlusion partielle de la corde ombilicale jusqu'd ce que le $\mathrm{pH}$ artériel fortal diminue de 7.30 d̀ des valeurs s'étendant de 7.08 d 7.13. Ces brebis ont été divisées en trois groupes: groupe A n'a reçu aucune anesthésie et ainsi a servi comme groupe témoin. Groupe B a reçu du thiopentone $\left(3 \mathrm{mg} \cdot \mathrm{kg}^{-1}\right)$ en injection intraveineuse suivi de 50 pour cent de protoxyde d'azote et 0.5 pour cent halothane dans l'oxygène pour 15 minutes, et group $C$ a reçu du thiopentone ( $3 \mathrm{mg} \cdot \mathrm{kg}^{-1}$ ) suivi de un pour cent d'halothane dans l'oxygène pour 15 minutes. Les fots sanguins cérébral, myocardique et rénal chez les foetus ont été mesurés par injection de microsphères radioactives après production de l'asphyxie 5 et 15 minutes après l'anesthésie.

$L$ 'anesthésie générale dans les deux groupes $B$ et $C$ a enrayé l'hypertension et la bradycardie produite par l'asphyxie fotale secondaire d l'occlusion de la corde ombilicale. Les changements les plus marqués sont survenus dans le groupe $B$ qui a reçu du protoxyde $d$ 'azote. Deux des six foetus de ce groupe sont morts après dix minutes de l' anesthésie. Il n'y avait cependant aucune différence significative pour le pH, la $\mathrm{PCO}_{2}$ et la $\mathrm{PO}_{2}$ chez les survivants de ce groupe et le groupe témoin.

De ces résultais on arrive à la conclusion que le protoxyde d' azote est inapproprié pour l' anesthésie dans des situations de détresse foctale sévère. 